\title{
Effects of Rapeseed Meal-Glucosinolates on Thyroid Metabolism and Feed Utilization in Rainbow Trout
}

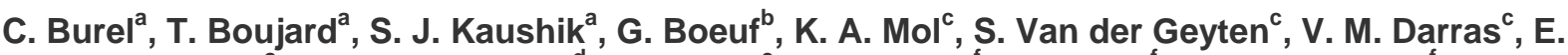 \\ R. Kühn ${ }^{c}$, B. Pradet-Balade ${ }^{d}$, B. Quérat ${ }^{e}$, A. Quinsac ${ }^{f}$, M. Krouti $^{f}$ and D. Ribaillier ${ }^{f}$
}

\footnotetext{
a Unité mixte INRA-IFREMER de Nutrition des Poissons, Station d'Hydrobiologie INRA, B.P. 3, 64310, Saint Péesur-Nivelle, France

${ }^{\mathrm{b}}$ Laboratoire de Physiologie des Poissons, IFREMER, Station de Brest, B.P. 70, 29280, Plouzané, France

c Laboratory of Comparative Endocrinology, Catholic University of Leuven, Naamsestraat 59, 3000, Louvain, Belgium

${ }^{d}$ CSIC-Centro Nacional de Biotecnologia, Campus de Canto Bianco-Ctra de Colmenar Viejo, Km 15,500, 28049, Madrid, Spain

e Laboratoire de Physiologie Générale et Comparée, Muséum National d'Histoire Naturelle, 7 rue Cuvier, 75231,

Paris Cedex, France

f'Laboratoire d'Analyses CETIOM, 270, avenue de la Pomme de Pin, 45160, Ardon, France
}

\begin{abstract}
Two rapeseed meals (RM1 and RM2), containing glucosinolates at a concentration of 26 and $40 \mu \mathrm{mol} / \mathrm{g}$, respectively, were incorporated at increasing levels (10, 20, and 30\% for RM1 and 30 and 50\% for RM2) in diets of juvenile rainbow trout. Disturbances in the thyroid axis appeared after 14 days of feeding (with a dietary incorporation level of 10\%). The dietary supplementation with T3 or iodine induced an increase in plasma T3 levels, compared to that in fish fed the RM diets, and reduced the deleterious effect of RM on growth. When trout were reared in seawater, there was also a slight increase in thyroid hormone levels. TSH treatment had no effect on the thyroid hormone plasma levels. The incorporation of $30 \%$ of RM1, which induced a lower dietary content of toxic compounds than RM2, led to a rapid decrease of plasma T4 and T3 levels, but growth was affected only after 6 months of feeding. During these studies, the deiodinase activities responded in a complex manner to restore plasma and tissue levels of T3.
\end{abstract}

Keywords: rapeseed; glucosinolates; growth; thyroid function; deiodinase activity; TSH; iodine; rainbow trout 


\section{INTRODUCTION}

The presence of dietary glucosinolates (GLS) is known to impair the thyroid function of humans (Astwood et al., 1949; McMillan et al., 1986), rats (Lo and Hill, 1971; Vermorel et al., 1987), cattle (Virtanen et al., 1958), pigs (Aumaître et al., 1989; Bourdon and Aumaître, 1990) and poultry (Akiba and Matsumoto, 1977), with deleterious consequences on growth.

GLS are not directly responsible for the deleterious effects on thyroid function (reviewed by Mawson et al., 1994b), but toxicity is caused by their derivative products, such as thiocyanate anions, vinyloxazolidinethiones, and isothiocyanates. This breakdown is mainly caused during the processing of rapeseed meal (RM) by myrosinase, which is a specific plant hydrolytic enzyme, but also by high temperatures or the activity of the intestinal microflora (Mawson et al., 1993). In fish of temperate areas such as rainbow trout (Oncorhynchus mykiss), the role played by intestinal microflora is negligible compared to that of terrestrial animals (Lesel, 1981), and the hydrolytic activity of intestinal microflora on GLS may be ruled out.

The thiocyanate anions are competitors of iodine for active transport across the cell membrane and for binding to tyrosine residues of thyroglobulin. Studies by Anke et al. (1980) and Ludke et al. (1985) on growing pigs have shown that iodine supplementation $(1 \mathrm{mg} / \mathrm{kg})$ to RM-based diets reduces the goitrogenic effects of thiocyanate anions and improves growth performance. The same treatment in rats (Vermorel and Evrard, 1987) led only to a reduced thyroid mass, without beneficial effects on growth and plasma thyroid hormone levels. Vinyloxazolidinethione inhibits the normal coupling reaction whereby two molecules of diiodothyronine (DIT) are joined to form thyroxine $\left(\mathrm{T}_{4}\right)$, or in smaller quantities DIT with monoiodothyronine (MIT) to form triiodothyronine $\left(\mathrm{T}_{3}\right)$. The action of isothiocyanates depends 
on their conversion into vinyloxazolidinethione or into thiocyanate anions (Marwson et al., 1994b).

Data from mammals suggest that the low circulatory levels of $T_{3}$ and $T_{4}$ due to the intake of RM stimulate excessive secretion of hypothalamic thyroid-stimulating hormone (TSH), which induces an increased thyroid follicle activity, resulting in a hypertrophy of the thyroid tissue (Mawson et al., 1994b). TSH $\beta$ mRNA has been isolated in several teleosts (Moriyama et al., 1997; Pradet-Balade et al., 1997, 1999) and it remains to be demonstrated that the low release of thyroid hormone observed in fish fed the RM-based diets is caused by a blockage at the level of thyroid hormone synthesis and not by a lack of TSH stimulation.

Data on the goitrogenic effects of dietary RM in fish are also available (Yurkowski et al., 1978; Higgs et al. 1982b; Hardy and Sullivan 1983; Leatherland et al. 1987; Hossain and Jauncey 1988; Teskeredzic et al. 1995; Webster et al., 1997; Burel et al. 2000a,b). The typical features of a hypothyroid condition are low $\mathrm{T}_{3}$ and $\mathrm{T}_{4}$ plasma levels accompanied by hyperactivity of the thyroid tissue in fish expressing a reduced growth rate. Recently, it was also shown in vitro that the hypothyroidal condition led to an adjustment of the deiodinase activities compensating for the low plasma level in $\mathrm{T}_{3}$ (Burel et al., 2000a,b). However, knowledge of the mechanisms involved in the goitrogenic effect of RM in fish is still rudimentary and the causal relationship between thyroid disturbance and reduced growth in fish fed this plant-product is still unclear. The incapacity to express normal growth could be attributed to a lack of $T_{3}$ according to the work of Leatherland et al. (1987), who showed that a dietary $\mathrm{T}_{3}$ supplementation of trout fed with RMbased diets can reduce the deleterious effect of RM on growth.

In this context, we initiated a series of experiments to determine to what extend the troubles in the physiology, the metabolism, and the growth performance are due to the GLS in trout fed RM-based diets and to evaluate the possibilities of reduction of these effects. Particular attention was paid to the regulatory role of deiodinase activity. The first objectives 
were to determine the sensitivity threshold of the thyroid axis of rainbow trout to the toxic derivatives of GLS contained in RM and to study the effects of these goitrogenic compounds on the thyroid status and the growth performance of fish over time. We examined also how a dietary supply of triiodothyronine or iodine affected growth and thyroid function of fish fed on RM-based diets, to assess the involvement of the goitrogenic derivatives of GLS in the deterioration of growth performance. Furthermore, we invastigated whether the hypothyroid condition was due to a blockage in hormone synthesis, as in mammals, by evaluating TSH synthesis in the pituitary of fish fed a RM-based diet and by analyzing the response of such fish to a TSH treatment. We have also studied the long-term effect of low thyroidal disturbances on growth and the long-term effects of a iodine supplementation. Finally, the potential interaction of iodine provided by the environment on the goitrogenic effect of dietary RM was evaluated.

\section{MATERIALS AND METHODS}

\section{Characteristics of RM used and feed preparation}

Two different methods of fat extraction processes were applied to rapeseed (Brassica napus). Details on these processes are given by Burel et al. (2000a). Pressure cooking led to a reduction of the intact GLS content in RM1 (26 $\mu$ mol GLS/g) and is susceptible to inactivation of the myrosinase. Direct oil extraction had no effect on the final intact GLS content of RM2 (40 $\mu \mathrm{mol}$ GLS/g).

Six experimental isonitrogenous and isoenergetic diets were formulated (Table 1): no RM (control diet); 10, 20, and 30\% RM1 (R1-10, and R1-20, and R1-30 diets); and 30 and 50\% RM2 (R2-30 and R2-50 diets). All the diets were enriched with a mineral mixture including $0.2 \mathrm{mg} / \mathrm{kg}$ of potassium iodine. The total dietary iodine levels (from 1.0 to 2.7 
$\mathrm{mg} / \mathrm{kg}$ ), estimated from the iodine content of the ingredients given by Ferrando and Blum (1989), were considered sufficient for salmonid species, even for those reared in freshwater. The amount of toxic breakdown products, estimated as shown below, was higher in the RM2based diet than in the RM1-based diets (Table 1).

\section{Experimental conditions}

Four experiments were undertaken with rainbow trout. Experiments 1, 2, and 3 were performed in freshwater at the INRA experimental fish farm (Donzacq, Landes, France) with 500-L tanks supplied with springwater $\left(17 \pm 1^{\circ}\right.$, flow rate $\left.10 \mathrm{~L} / \mathrm{min}\right)$. Experiment 4 was carried out at the IFREMER experimental facilities (Môle Sainte Anne, Brest, France) in 2000-L tanks supplied with freshwater $\left(10 \pm 1^{\circ}\right.$, salinity $0-2 \%$, flow rate $\left.30 \mathrm{~L} / \mathrm{min}\right)$ or seawater $\left(12 \pm 1^{\circ}\right.$, salinity $35 \%$, flow rate $\left.30 \mathrm{~L} / \mathrm{min}\right)$.

In experiments 1,2 , and 3 , feed was distributed by hand, twice a day, to apparent satiety and the total feed intake was recorded. In experiment 4 , feed was distributed in excess by automatic feeders over a period of $6 \mathrm{~h}$ per day.

\section{Experiment 1}

Five diets were used in this experiment: control, R1-10, R1-20, R1-30, and R2-50. The R1 diets allowed a graded level of RM and GLS derivatives, and the R2-50 diet was used as negative control because of its high content of GLS derivatives.

Rainbow trout with an average body weight of $22 \mathrm{~g}$ were randomly allotted to 15 tanks (50 fish per tank, 3 tanks by treatment). After a 1-week adaptation period, the fish were fed the experimental diets (in triplicate) for 58 days. A series of blood samples was taken

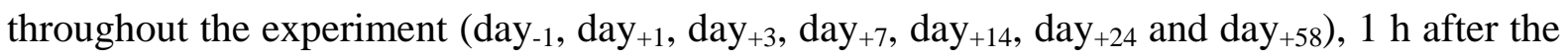
morning meal. The sample day -1 was obtained from 30 fish of the initial population, on a 
basis of 2 fish per tank. On other sampling days, 10 fish per tank (30 per dietary treatment) were sampled. Blood samples were obtained from vessels near the caudal peduncle by means of heparinized syringe and were immediately centrifuged (3000 rpm, $10 \mathrm{~min}$ ). Plasma was stored at $-20^{\circ}$ until $\mathrm{T}_{4}$ and $\mathrm{T}_{3}$ measurements. At day ${ }_{+7}$, day ${ }_{+24}$, and day ${ }_{+58}$, the liver, brain and kidney from the bled fish were removed, immediately frozen in liquid nitrogen, and subsequently stored at $-80^{\circ}$. The amount of food distributed and the increase in fish biomass were measured for each replicate tank between days of blood and tissues sampling.

\section{Experiment 2}

In this experiment, the control diet, the R2-50 diet (high content of toxic compounds), and the same diet supplemented with either $1 \mathrm{mg} / \mathrm{kg}$ of iodine (R2-50-I), $10 \mathrm{mg} / \mathrm{kg}$ of $\mathrm{T}_{3}$ (R250- $\left.\mathrm{T}_{3} 10\right)$, or $20 \mathrm{mg} / \mathrm{kg}$ of $\mathrm{T}_{3}\left(\mathrm{R} 2-50-\mathrm{T}_{3} 20\right)$ were used. 3,5,3'-Triiodo-L-thyronine ( $\mathrm{T}_{3}$, Sigma) was dissolved in $100 \mathrm{ml}$ ethanol, and the $\mathrm{pH}$ was raised to 10.2 with $1 \mathrm{M} \mathrm{NaOH}$. Iodine (KI, Sigma) was dissolved in $100 \mathrm{ml}$ distilled water. The solutions were sprayed onto the dietary ingredients during mixing. After granulation and evaporation of ethanol or water, the diets were stored at $-20^{\circ} \mathrm{C}$.

Rainbow trout with an average body weight of $24 \mathrm{~g}$ were randomly allotted to 15 tanks (50 fish per tank). After a 1-week adaptation period, the fish were fed the experimental diets (5 diets in triplicate) for 64 days. Fish biomass was determined for each replicate at day, day+27, and day ${ }_{+55}$. After 58 days of experimental feeding, blood and tissue (liver, brain, and kidney) samples were taken from 15 fish per dietary treatment (5 fish per tank), as described for Experiment 1.

Among the three groups of fish fed the control and the R2-50 diets, 20 fish were kept from each tank after the first samplings $\left(\mathrm{day}_{+58}\right)$. At day+63, after the morning meal, 5 fish per tank were injected with $100 \mu \mathrm{l}$ of a $100 \mathrm{mg} / \mathrm{L}$-thyroid-stimulating hormone solution (bovine 
TSH, Sigma, diluted in 9\%o saline solution), 5 fish with $100 \mu \mathrm{l}$ of a $200 \mathrm{mg} / \mathrm{L}-\mathrm{TSH}$ solution, and 5 fish with $100 \mu \mathrm{l}$ of 9\%o saline solution (sham-treated). The remaining 5 fish were considered untreated control. The next morning (day+64), after the morning meal, blood samplings were taken (as previously described) from 3 fish per tank, to total 9 fish per treatment. Tissue samples were taken (as previously described) from fish injected with 200 mg/L-TSH and sham-treated fish.

\section{Experiment 3}

A control diet was compared to the R1-30 diet, supplemented or not with $2 \mathrm{mg} / \mathrm{kg}$ of iodine (R1-30-I). The iodine supplement was added as described for Experiment 2.

Rainbow trout with an average body weight of $34 \mathrm{~g}$ were randomly allotted to nine tanks with 50 fish per tank. After a 1-week adaptation period, the fish were fed the experimental diets (three diets in triplicate) for 164 days. Fish biomass was determined for

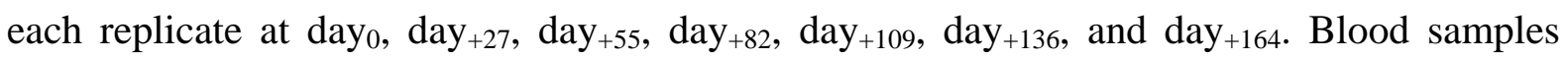
were taken at day ${ }_{+58}$ and day+164 from 15 fish per dietary treatment (5 fish per replicate), $1 \mathrm{~h}$ after the morning meal as previously described for Experiment 1.

After the last sampling $($ day+164 $), 12$ fish fed the control and R1-30 diets were kept from each tank, in the context of a further trial not described here. These fish were fed as described before during 1 additional month, after which $\left(\right.$ day $\left._{+194}\right)$ blood samples and pituitaries were removed, the latter being rapidly frozen in liquid nitrogen for storage before RNA extraction.

\section{Experiment 4}

Rainbow trout with an average body weight of $160 \mathrm{~g}$ and previously reared in freshwater were randomly allotted into six tanks (55 trout per tank). After a 1-month 
adaptation period to the environmental conditions, i.e., fresh water or seawater, the fish were fed the control, R1-30, or R2-30 diet for 25 days. Each experimental diet was distributed to a batch of fish placed in freshwater and a batch in seawater. Then, blood samples were taken from 15 fish per tank, $1 \mathrm{~h}$ after the morning meal as previously described for Experiment 1.

\section{Analytical methods}

Nutrient retention efficiencies: Whole-body samples (10 fish at the beginning and $3 \times 5$ fish per treatment at the end of Experiment 2) were homogenized and freeze-dried for composition analyses. Analyses of diets and whole body samples were made according to the following procedures: dry matter after drying at $105^{\circ}$ for $24 \mathrm{~h}$; protein $(\mathrm{N} \times 6.25)$ by the Kjeldahl method after acid digestion; gross energy in an adiabatic bomb calorimeter (Parr); fat after extraction with petroleum ether by the Soxhlet method, and, finally, total phosphorus by spectrophotometric analysis of the phosphovanadomolybdate complex after mineralization and acid digestion (ISO/DIS 6491 method). Nutrient retention efficiencies were calculated as Retention $=100 \times(\mathrm{FBW} \times$ final carcass nutrient or energy content $-\mathrm{IBW} \times$ initial carcass nutrient or energy content) / nutrient or energy intake, with IBW, FBW, and ABW as initial, final, and average body weight, respectively.

GLS and breakdown products: To evaluate the amount of toxic compounds present in the different diets, GLS were analyzed in RM1, RM2, and in diets as described in Quinsac et al. (1991). The amount of breakdown products from GLS in the diets was estimated with the considerations that the GLS content measured in the untreated RM (RM2) is the initial amount of intact GLS without hydrolysis and that the final amount of intact GLS measured in the diets resulted from the hydrolysis occurring during the oil extraction process in the case of the RM2-based diets or from the granulation of the diets in the case of the RM1-based diets. The following calculation was used for the RM1- and RM2-based diets (Table 1): 
Amount of breakdown products $=($ Amount of GLS in dry matter of RM2 $\times \%$ dietary incorporation of RM1 or RM2 × \% dry matter of diet) - (amount of GLS measured in diet $\times$ $\%$ dry matter of diet).

The amount of breakdown products was expressed as equivalent $\mu$ mol of GLS hydrolysed. This estimation can be overestimated because of the volatile breakdown products which may be lost during the oil extraction or the granulation. Results are expressed in $\mu \mathrm{mol} / \mathrm{g}$, but squaring values in $\mu \mathrm{g} / \mathrm{g}$ can be obtained with the following relationships: 0.432 and $0.123 \mu \mathrm{mol}=1 \mu \mathrm{g}$ for GLS and GLS breakdown products in RM, respectively.

Measurement of the thyroidal status: For the assay for thyroid hormones in plasma, plasma thyroid hormone $\left(\mathrm{T}_{4}\right.$ and $\mathrm{T}_{3}$ ) levels were measured for each fish (except in Experiment 1, where the blood of two fish was combined before centrifugation) with a radio-immunoassay (RIA) described by Boeuf and Prunet (1985), and modified by Martinez et al. (1995). The detection limits for the $T_{4}$ and $T_{3}$ RIAs were 1.25 and $0.62 \mathrm{ng} / \mathrm{ml}$, respectively. The percentage of specific binding obtained was 42 for $T_{4}$ and 55 for $T_{3}$, and the percentage of unspecific binding was 10 for $\mathrm{T}_{4}$ and 9 for $\mathrm{T}_{3}$. These percentages were estimated at a hormone level of $80 \mathrm{ng} / \mathrm{ml}$. The intraassay coefficient of variation was $10 \%$ for both $\mathrm{T}_{4}$ and $\mathrm{T}_{3}$.

The different types of deiodinase activities present in rainbow trout (type I:D1; type II: D2; type II: D3) and the tissues that contain the highest levels of enzymatic activity (liver, brain, and kidney) were identified in a previous study (Mol et al., 1998). For the deiodinase assay, in the present study, the D1 activity was measured in kidney, D2 in liver, and D3 activity in liver and brain (tissues pooled $\times 5, n=3$ ) following the technique described in detail in Burel et al. (2000a). The deiodinase activities in microsomal fractions of tissues are expressed as femtomoles of substrate converted per milligram of protein per minute. 
For the RNA extraction and Northern blot analysis of the TSH $\beta \beta$ mRNA levels, total pituitary RNAs from individual pituitaries were extracted in RNA+ (Bioprobe) as described previously (Pradet-Balade et al., 1997). Total RNAs were separated through $1.2 \%$ (w:v) agarose-formaldehyde gels, transferred to membranes (Duralon-UV, Stratagene), and treated as previously described (Quérat et al., 1991). For hybridizations, the isolated 180 bp TSH $\beta \beta$ and 865 bp $\beta \beta$-actin cDNA fragments were used as templates for random-primed labeling, and hybridization was performed as previously described (Pradet-Balade et al., 1997). Scanning densitometry was performed with a Phosphor Imager (Molecular Dynamics). Individual TSH $\beta \beta$ densitometric values were corrected by $\beta \beta$-actin values for RNA loading standardization.

\section{Data analysis}

Results are presented as means with standard deviation (SD). To test the effect of dietary treatments, data were subjected to a one-way analysis of variance $(P<0.05)$, and when appropriate, means were compared by the Tukey's multiple range test for each experiment.

\section{RESULTS}

\section{Experiment 1}

The dietary incorporation of RM1 up to 30\% did not lead to any difference in terms of growth performance, voluntary feed intake, or feed efficiency after 58 days of experimental feeding. In contrast, the final body weight of the fish fed the R2-50 diet was significantly lower than those of fish fed the other diets after 24 days (data not shown), and at day+58, it was 30\% lower (Table 2). The decrease of the daily growth index (DGI) was accompanied by 
a decrease in feed efficiency (FE), and the voluntary feed intake (VFI) was not significantly affected (Table 2).

The plasma $\mathrm{T}_{4}$ and $\mathrm{T}_{3}$ levels (Fig. 1) were significantly reduced after 14 days of feeding, even with only 10\% of RM1 incorporated in the diet of trout. The drop in plasma $\mathrm{T}_{3}$ and $\mathrm{T}_{4}$ was more severe in fish fed the R2-50 diet. Whereas the effects of dietary $\mathrm{RM}$ on plasma $\mathrm{T}_{4}$ levels were still pronounced in all groups after 58 days of feeding, only high levels of dietary RM (30\% of RM1 and 50\% of RM2) had significant effects on plasma $\mathrm{T}_{3}$ levels.

No significant effect of RM intake was observed on in vitro D1 activity in kidney of trout sampled after 7, 24, or 58 days of feeding (Fig. 2A). After 58 days of feeding a large increase of the D2 activity in liver was observed, even in RM1-10 fed-fish and this effect was even visible after 7 days for R1-30 and R2-50 fed-fish (Fig. 2B). No significant effect of the RM level on the in vitro D3 activity in liver was found (Fig. 2C). In contrast, a reverse relationship between dietary level of RM and brain D3 activity was noted even after 7 days of feeding (Fig. 2D). This effect was even more pronounced after 58 days, when a decrease in brain D3 activity was observed in fish fed all the RM-based diets.

\section{Experiment 2}

After 55 days, the dietary incorporation of 50\% RM2 led to a significant $(P<0.05)$ drop of the plasma $\mathrm{T}_{4}$ and $\mathrm{T}_{3}$ levels compared to those in control fish (Fig. 3A). In addition, a significant decrease of the growth rate (Fig. 3B), an increase of the feed intake, and a decrease of the feed efficiency (Fig 3C) were observed. The lower feed utilization was characterized by a significant lower retention of nitrogen, phosphorus, and energy (Table 3).

The addition of 10 and $20 \mathrm{mg} / \mathrm{kg}$ of $\mathrm{T}_{3}$ in the RM2-based diet led to a strong increase $(\mathrm{P}<0.05)$ of the plasma $\mathrm{T}_{3}$ level (Fig. 3A), whereas plasma $\mathrm{T}_{4}$ did not change compared to R250 fed fish. The drop in growth rate was significantly reduced in both cases (Fig. 3B). The feed 
intake was strongly increased, but the feed efficiency remained as low as in R2-50-fed fish (Fig. 3C). The dietary supplementation with 10 and $20 \mathrm{mg} / \mathrm{kg}$ of $\mathrm{T}_{3}$ had no significant effect on the retention of nitrogen and energy, but significantly reduced the drop in phosphorus retention (Table 3).

The supplement of $1 \mathrm{mg} / \mathrm{kg}$ of iodine in the R2-50 diet led to a significant increase of the plasma $T_{3}$ level, even though the plasma $T_{4}$ level remained lower (Fig. 3A). The growth rate was significantly higher than that of fish fed the unsupplemented R2-50, but was still lower than that of the control fish (Fig. 3B). The feed intake was unaffected, but the feed efficiency was significantly improved (Fig. 3C), with a significant reduction of the drop in nitrogen, phosphorus, and energy retention (Table 3).

The dietary and hormonal treatments also affected the deiodinase activities in trout. The incorporation of 50\% of RM2 into the diet, inducing a significant drop in plasma $\mathrm{T}_{4}$ and $\mathrm{T}_{3}$ levels, led to a significant increase of the D2 activity in liver (Fig. 4B) and a significant decrease of the D3 activity in brain (Fig. 4C) compared to that of control fish. The D1 activity in kidney (Fig. 4A) and the D3 activity in liver (Fig. 4C) remained unchanged. The significant increase of the plasma $T_{3}$ levels induced by the dietary $T_{3}$ supplementation in fish fed the RM2-based diets led to a reduction of the D2 activity in the liver to a level similar to that of control fish (Fig. 4B). However, it led also to a significant increase in D3 activity in the liver and in the brain (Fig. 4C). The dietary iodine supplementation induced a slight increase in plasma $T_{3}$ levels in comparison to that induced by the $T_{3}$ supplementation and did not lead to any change in deiodinase activities compared to fish fed the RM2-based diet without supplementation (Fig. 4).

Fish fed the control diet and injected 100 and $200 \mathrm{mg} / \mathrm{L}$ of TSH significantly increased their plasma levels in $\mathrm{T}_{4}$ after $24 \mathrm{~h}$, without any change in the $\mathrm{T}_{3}$ levels (Fig. 5). In fish fed the R2-50 diet, the TSH treatment had no effect on the plasma levels of $T_{3}$ nor $T_{4}$. 
The sham injection had no effect on the thyroid hormone levels compared to the control fish. Irrespective of the dietary treatment, TSH injection had no significant effect after $24 \mathrm{~h}$ on the D1 activity in kidney, the D2 activity, or the D3 activity in liver or brain (Table 4).

\section{Experiment 3}

Compared to the control fish, the dietary incorporation of $30 \%$ RM1 led to a significant decrease of ca. $50 \%$ of the plasma $\mathrm{T}_{4}$ and $\mathrm{T}_{3}$ levels after 58 days of feeding and ca. $50 \%$ of the plasma $\mathrm{T}_{4}$ and $40 \%$ of the plasma $\mathrm{T}_{3}$ levels after 164 days (Fig. 6A). The difference between the body weight of the control fish and that of the fish fed the R1-30 diet was ca. 15\% after 55 days of feeding, and 32\% after 164 days (Fig. 7). Feed intake, stimulated during the first period, was inhibited over 164 days and feed efficiency was lower than that in control fish, but this reduction was less pronounced after 164 days, (Fig. 6C). After 194 days of feeding, plasma $\mathrm{T}_{4}$ still seemed to be reduced in the R1-30-fed fish (but this diminution was not statistically significant). Correlatively, there was a high, significant increase (more than 60 -folds) of pituitary TSH $\beta \beta$ mRNA levels compared to the control levels (177 \pm 172 vs. $2.83 \pm 2.4$ in arbitrary units, $P<0.001)$.

A significant beneficial effect of the dietary iodine supplementation of $2 \mathrm{mg} / \mathrm{kg}$ was observed after 164 days on plasma $\mathrm{T}_{3}$ levels, which became similar to that of the control group (Fig. 7A). In terms of growth performance, a significant long term effect of the iodine supplementation was also visible as shown by the growth rate measured during the second period (Fig. 7B). Feed intake and feed efficiency were not significantly increased in the long term compared to fish fed the unsupplemented R1-30 diet (Fig. 7C). 


\section{Experiment 4}

When fish were reared in fresh or seawater and fed for 25 days with diets containing GLS (Fig. 8), the $T_{4}$ and $T_{3}$ levels were significantly reduced compared to those of the control fish. There was a significant difference in the $T_{4}$ plasma levels in fish reared in fresh or seawater, whatever the diet. In seawater, plasma $\mathrm{T}_{4}$ levels were $41 \%$ higher in fish fed the control diet and 48\% higher in fish fed the RM2-based diet than in freshwater for the same dietary conditions.

\section{DISCUSSION}

In trout, the mode of action of the GLS derivatives appears to be similar to those described in terrestrial animals by Mawson et al. (1994ab), and the role played by the thiocyanate anions is confirmed (see fig. 9). In trout fed diets containing RM1, disturbances in the thyroid axis appeared quickly (from 14 days of feeding) and were already observed at low dietary incorporation (10\%). However, growth performance of trout was reduced much later (after 80 days of feeding) and only with a higher level of RM1 dietary incorporation (30\%). In the case of a high dietary level of GLS derivatives (50\% of RM2), the thyroidal disturbances were much stronger and the growth performance was reduced more quickly (after only 24 days). The resulting shortage in bio-active $T_{3}$ is, at least, partially responsible for the lower growth performance, leading to a reduction of the utilization of dietary proteins, energy, and phosphorus. Indeed, when the diminution in thyroid hormones is counteracted by iodine or $\mathrm{T}_{3}$ supplementation, a partial recovery of the growth is observed. An extra-supply of iodine from a marine environment may also reduce the thyroid troubles, as seen for the fish fed the R2-50 diet. This study showed also that the deiodinase activities respond to thyroid hormone variations in a complex and coordinated way to maintain a sufficient plasma and tissue $\mathrm{T}_{3}$ level. 


\section{Mode of action of GLS derivatives on the pituitary-thryoid axis in the trout}

As previously shown in numerous studies (see Introduction), the intake of RM containing GLS derivatives led to a shortage in the release of the thyroid hormones in the blood of trout. Our results supports the hypothesis that such a decrease is not caused by a lack of pituitary stimulation, but rather by a blockage in the activity of the thyroid follicles, as it has been hypothetized in terrestrial animals (Mawson et al., 1994b). Indeed, injections of TSH did increase thyroid hormone levels in fish fed the control, RM-free diet, but not in the trout fed a RM-based diet. Furthermore, a hypertrophy of the thyroid tissue in trout fed a RMbased diet has been shown previously (Burel et al., 2000a) and our present data suggest that this hypertrophy is due to an increase in TSH stimulation. Indeed, the TSH $\beta$ mRNA expression levels were much higher in fish fed with RM than in the control. Low plasma thyroid hormone levels would then increase TSH $\beta$ mRNA expression level -hence, very likely, TSH synthesis- and TSH liberation, as has been already described in other teleosts (Larsen et al., 1997; Moryama, 1997; Pradet-Balade et al., 1997, 1999).

Furthermore, the deleterious effect of the thiocyanate anions, competitors of iodine in the thyroid metabolism, has been demonstrated in trout and pigs (Anke et al., 1980; Ludke et al., 1985).

In the fish fed a diet with a low level of toxic compounds (30\% of RM1), iodine supplementation (2 mg/kg) significantly affected plasma $T_{3}$ levels only after 6 months of feeding. When fish were fed a diet with a higher level of toxic compounds (50\% of RM2), the effect of the iodine $\left(1 \mathrm{mg} / \mathrm{kg}\right.$ ) on plasma $\mathrm{T}_{3}$ was stronger and quicker ( 2 months). The iodine supplementation did not allow a complete recovery of plasma $T_{3}$ level and growth rate, compared to control fish. The dose of iodine used in this study may have been too low to counteract the effect of thiocyanate anions. Alternatively, the presence of other goitrogenic 
compounds such as vinyloxazolidinethiones, nitriles, etc., the effects of which remain to be studied in fish, may disturb the pituitary-thyroid axis at additional levels, so that iodine supplementation would not completely counteract the global effect of the diet. The difference between the two diets with regard to rapidity and intensity of the response of fish to the iodine treatment may be due to a different ratio in thiocyanate anions and other GLS derivatives in the two RMs used.

In fish, iodine may also be provided by the ambient environment by active transport across the gills (Lall, 1988). In the present study, the seawater, more rich in iodine than the freshwater, induced a slight increase in plasma $\mathrm{T}_{4}$ in fish fed with the RM2 diet. Those fish also showed the stronger response to the iodine supplementation. This supports the idea that the different content of thiocyanate anions in the two RMs is responsible for the different effects of iodine supplementation. In addition, this result also suggests that marine fish species could be less susceptible to RM intake than freshwater fish species, at least for some diets, with respect to iodine supply. Our data obtained in turbot (Burel et al., 2000b) are in good agreement with this hypothesis.

\section{Compensatory effects of the deiodinases}

We have already suggested that in trout and turbot the deiodinase activities may play an important role in the regulation of the plasma $T_{3}$ levels in fish fed RM-based diets (Burel et al., 2000a,b). Plasma $\mathrm{T}_{3}$ and $\mathrm{T}_{4}$ decreased quickly (after 14 days of feeding) in trout in a dose-dependent response to GLS breakdown products. The changes in the deiodinase activities, in compensation to the shortage in bioactive $T_{3}$ were sensitive and took place even at the lowest incorporation (10\%) of RM. The deiodinase response in liver and brain was observed after only 7 days of feeding, even before the decrease in plasma thyroid hormone levels. This suggests a fast change in $\mathrm{T}_{3}$ levels in these tissues. After 2 months of feeding, the 
compensatory activities of deiodinases were very high, but efficient only up to a level of $20 \%$ of dietary RM.

As described in Burel et al. $(2000 a, b)$, the stimulation of the in vitro D2 activity in liver suggested the possibility that in vivo $\mathrm{T}_{3}$ production from the circulating $\mathrm{T}_{4}$ was increased. In addition, the decrease of in vitro $\mathrm{D}_{3}$ activity observed in brain suggested that the in vivo degradation of $\mathrm{T}_{3}$ was reduced, probably to protect the brain against low $\mathrm{T}_{3}$ levels. In the present study, contrary to earlier observations in trout (Burel et al., 2000a), the intake of toxic compounds had no effect on in vitro D1 activity, an enzyme degrading $\mathrm{rT}_{3}$ but also converting $\mathrm{T}_{4}$ into $\mathrm{T}_{3}$ as suggested by Kühn et al. (1993).

When the RM-based diets were supplemented with iodine, the plasma $T_{3}$ level, but not the $\mathrm{T}_{4}$, was increased. The in vitro deiodinase activities remained unchanged compared to those in fish fed the unsupplemented RM-based diets. If the iodine supplementation really enhanced thyroid hormone synthesis in thyroid follicles as discussed above, that was not sufficiently enough to restore a normal thyroid metabolism, and the level of $\mathrm{T}_{4}$ conversion into $\mathrm{T}_{3}$ remained high.

In fish fed a RM-based diet, $\mathrm{T}_{3}$ supplementation induced abnormally high plasma $\mathrm{T}_{3}$ levels, whereas plasma $\mathrm{T}_{4}$ levels remained unchanged. In addition, there was a strong inhibition of the in vitro conversion of $\mathrm{T}_{4}$ into $\mathrm{T}_{3}$ in liver and a strong stimulation of the in vitro degradation of $T_{3}$ in liver and brain, probably as a compensatory mechanism to the $T_{3}$ overcharge. This is in agreement with the results of Sweeting and Eales (1992) and MacLatchy and Eales (1993).

In the present study, the short time between the TSH injection and the blood sampling (24 h) could explain the lack of deiodinase responses. Alternatively, a higher $\mathrm{T}_{4}$ clearance could be provoked by an increase in conjugation and/or excretion. 


\section{Relationship between thyroid disturbances and growth capacity of trout}

Several authors, including Eales and Shostak (1985), Boeuf and Gaignon (1989), McCormick and Saunders (1990) and Gomez et al. (1997), have suggested a close relationship between plasma $T_{3}$ levels and growth in fish, probably through the effect of $T_{3}$ on the intermediary metabolism (for review, Leatherland 1994). Moreover, Leatherland et al. (1987) have shown that a dietary $\mathrm{T}_{3}$ supplementation to trout fed RM-based diets led to an improvement in the growth performance compared to those in the trout fed the unsupplemented RM diets. Our data suggest that a certain amount of bioactive $T_{3}$ is necessary to support a « normal » growth of the fish and that below a threshold level, growth capacity is reduced, with a lower body retention of the dietary nitrogen, phosphorus and energy.

In the present study, $\mathrm{T}_{3}(10$ and $20 \mathrm{mg} / \mathrm{kg}$ ) supplementation of RM-based diets led to higher plasma $\mathrm{T}_{3}$ levels and increased growth performance, but without reaching that of the control group. This improvement is likely due to a stimulation of feed intake, but feed efficiency remained low, even if the body retention of phosphorus was improved. Iodine supplementation also significantly increased plasma $\mathrm{T}_{3}$ level, though to a lower extent than the $\mathrm{T}_{3}$ supplementation, and growth rate was not as low as that of the fish fed the unsupplemented RM diet. In this case, the improvement of the growth performance was due to an increase in the feed efficiency and an improvement of the retention efficiencies in nitrogen, phosphorus, and energy. These results tend to confirm that the shortage in $\mathrm{T}_{3}$ is, at least partly, responsible for low feed efficiency observed in fish fed the RM-based diets. The implication of thyroid hormones in the intermediary metabolism of fish is well known (Leatherland, 1994), but the lack of data on the digestibility of nutrients and energy contained in the supplemented and unsupplemented diets prevents conclusions about the respective effects of a shortage in $T_{3}$ on both digestive and metabolic utilization of dietary nutrients and energy. 
The difference between the two RMs with regard to the rapidity and intensity of the response of the fish to the iodine treatment may be due to a different ratio in thiocyanate anions and other GLS derivatives in the two RMs used. In the case of the $T_{3}$ treatment, the results are only partially in agreement with those of Leatherland et al. (1987). Indeed, with the same level of $T_{3}$ supplementation, they observed a growth rate similar to that of the control fish, with an increase in feed efficiency. Our results suggest that the shortage in $\mathrm{T}_{3}$ only partially explains the reduced growth of fish. The lower growth rate could also be due, in part, to a lower nutritional value of the diet, due to a high level of dietary incorporation of RM containing fibers, tannins, and phytic acid. However, supraphysiological plasma $T_{3}$ concentrations induce a catabolic state and can lead to cranial malformations, a phenomenon that we observed in some fish in the present experiment (data not presented), and a depression of growth (Higgs et al., 1982a). In our study, the mean plasma $\mathrm{T}_{3}$ levels in supplemented fish

were four- to ninefold higher than those in unsupplemented fish, whereas in the study of Leatherland et al. (1987), they were only two- to fourfold higher. Another test with a lower dietary $\mathrm{T}_{3}$ supplementation (lower than $10 \mathrm{mg} / \mathrm{kg}$ ) would be necessary to determine to what extent the thyroidal disturbance and of the hypothetical low nutritional value of the RM used here are responsible for the lower growth of trout.

\section{Threshold of sensitivity for an effect on thyroid status and growth}

In this study, the dietary incorporation of RM with a low content of GLS at a level of $30 \%$ led to a decrease in the growth performance of rainbow trout only after 80 days of feeding, whereas disturbances in the thyroidal axis were already observed at a level of $10 \%$ of incorporation and after only 14 days of feeding. The results suggests that a plasma $\mathrm{T}_{3}$ level decreased by about 30\% can nevertheless allow a rather normal growth for up to 2 months, but not at longer term (6 months). 
An estimation of the amounts of the breakdown products from GLS in the diet used was made, suggesting that $1.5 \mu \mathrm{mol}$ GLS derivatives per gram of diet are sufficient to induce reduced plasma $T_{4}$ levels in juvenile rainbow trout. However, for diets containing up to 2.4 $\mu$ mol of GLS breakdown products per gram or more, it seems that even if the plasma $T_{4}$ levels are strongly reduced, a compensatory effect due, at least partly, to $\mathrm{T}_{4}$ desiodination into $\mathrm{T}_{3}$ led to unaltered plasma $\mathrm{T}_{3}$ levels. It remains to be demonstrated that this adjustment is also sufficient for normal growth at long term. A high dietary content in toxic compounds, for instance a level of about $17 \mu \mathrm{mol} / \mathrm{g}$ due to the incorporation of $50 \%$ of untreated RM (RM2) in the diet, leads to a drastic reduction of both plasma $\mathrm{T}_{3}$ and $\mathrm{T}_{4}$ levels accompanied by a rapid decrease of the growth rate (after 24 days of feeding).

Our data are in accordance with those of Yurkowski et al. (1978), Hardy and Sullivan (1983), and Leatherland et al. (1987), who had all determined a minimum level of GLS and GLS breakdown products which induced thyroid disturbance in trout in the range of 1-2 $\mu \mathrm{mol} / \mathrm{g}$ of diet. In relation to growth performance, our results suggest a critical dietary content of toxic compound $(\leq 3.7 \mu \mathrm{mol} / \mathrm{g}$ of diet) slightly higher than that of those authors (1$2 \mu \mathrm{mol} / \mathrm{g}$ of diet), but lower than that of Abdou Dade et al. (1990), who have shown that a RM-based diet containing around $10 \mu \mathrm{mol} / \mathrm{g}$ of GLS had no effect on the growth of rainbow trout. In fact, the comparison of these results is difficult, because of the potential differences in the nutritional value of the RM used, the profile of GLS and GLS breakdown products in the diet, and the different ways to express the GLS dietary contents. Authors indicate either the total amount of intact GLS, only that of some individual GLS such as progoitrine, or only the amount of isothiocyanates and oxazolidinethione. When compared to terrestrial animals (reviews in Mawson et al, 1994a, b), rainbow trout seem to have a thyroid sensitivity similar to that of monogastric animals, such as rat (0.5-4 $\mu \mathrm{mol} / \mathrm{g}$ of RM-based diet), swine (2-3 
$\mu \mathrm{mol} / \mathrm{g})$, and growing poultry $(1.4 \mu \mathrm{mol} / \mathrm{g})$, but a higher sensitivity than that of a young ruminant such as the calf $(8 \mu \mathrm{mol} / \mathrm{g})$.

\section{ACKNOWLEDGMENTS}

This work was partially supported by the CETIOM (Centre Technique Interprofessionnel des Oléagineux Métropolitains, France), the UNIP (Union Nationale Interprofessionnelle des Protéagineux, France), and the KU Leuven Onderzoeksraad (project OT/94/11). The authors gratefully acknowledge the skilled technical assistance of D. Blanc,

J. Brèque, Y. Hontang, A. Le Roux, L. Noterdaeme, P. Peyrotte, F. Sandres, A. Sévère, F. Terrier, C. Vachot, W. Van Ham, and F. Voets.

\section{REFERENCES}

Abdou Dade, B., Aguirre, P., Blanc, D., and Kaushik, S. J. (1990). Incorporation du colza 00 sous forme de tourteau ou d'amande dans les aliments de la truite arc-en-ciel (Oncorhynchus mykiss): performance zootechnique et digestibilité (Incorporation of rapeseed 00 shape of cattle cake or almond in diets for rainbow trout (Oncorhynchus mykiss): zootechnical performance and digestibility). Bulletin Français de la Pêche et de la Pisciculture 317, 50-57.

Akiba, Y., and Matsumoto, T. (1977). Effects of graded doses of goitrin, a goitrogen in rapeseed, on synthesis and release of thyroid hormone in chicks. Jap. J. Zootech. Sci. 48, 757-765.

Anke, M., Schwarz, S., Hennig, A., Groppel, B., Grun, M., Zenker, G., and Glos, S. (1980). Der einfluss zusächtlicher zink- und jodgaben auf rapsextraktionsschrotbedingte schäden beim schwein. Monatsh. Veterinärmed 35 (3), 90-94. 
Astwood, E. B., Greer, M. A., and Ettlinger, M. G. (1949). L-5-vinyl-2-thiooxazolidone, an antithyroid compound from yellow turnip and from brassica seeds. J. Biol. Chem. 181, 121-130.

Aumaître, A., Bourdon, D., Peiniau, J. and Bengala Freire, J. (1989). Effect of graded levels of raw and processed rapeseed on feed digestibility and nutrient utilization in young pigs. Anim. Feed Sci. Technol. 24, 275-287.

Boeuf, G., and Gaignon, J.L. (1989). Effects of rearing conditions on growth and thyroid hormones during smolting of atlantic salmon Salmo salar L. Aquaculture 45, 29-38.

Boeuf, G., and Prunet P. (1985). Measurements of gill $\left(\mathrm{Na}^{+}-\mathrm{K}^{+}\right)$ATPase activity and plasma thyroid hormones during smoltification in Atlantic salmon (Salmo salar L.). Aquaculture 45, 111-119.

Bourdon, D. and Aumaître, A. (1990). Low-glucosinolate rapeseeds and rapeseed meals: effect of technological treatments on chemical composition, digestible energy content and feeding value for growing pigs. Anim. Feed Sci. Technol. 30, 175-191.

Burel, C., Boujard, T., Escaffre, A. M., Kaushik, S. J., Boeuf, G., Mol, K., Van Der Geyten, S., and Kühn, E. R. (2000a). Dietary low-glucosinolate rapeseed meal affects thyroid status and nutrient utilization in rainbow trout (Oncorhynchus mykiss). Br. J. Nutr. 83, 653-664.

Burel, C., Boujard, T., Kaushik, S. J., Boeuf, G., Van Der Geyten, S., Mol, K., Kühn, E. R., Quinsac, A., Krouti, M., and Ribaillier, D. (2000b). Potential of plant-protein sources as fish meal substitutes in diets for turbot (Psetta maxima): growth, nutrient utilisation and thyroid status. Aquaculture 188, 363-382.

Eales, J.G., and Shostak, S. (1985). Correlations between food ration, somatic growth parameters and thyroid function in artic charr, Salvelinus alpinus L. Comp. Biochem. Physiol. 80A, 553-558. 
Ferrando, R., and Blum, J. C., (Eds.) (1989) L'alimentation des animaux monogastriques: porc, lapin, volaille (Nutrition of monogastric animals: pig, rabbit, poultry), 293 p. INRA, Paris, France.

Gomez, J.M., Boujard, T., Boeuf, G., Solari, A., and Le Bail, P.-Y. (1997). Individual diurnal plasma profiles of thyroid hormones in rainbow trout (Oncorhynchus mykiss) in relation to cortisol, growth hormone, and growth rate. Gen. Comp. Endocrinol. 107, 74-83.

Hardy, R. W., and Sullivan, C. V. (1983). Canola meal in rainbow trout (Salmo gairdneri) production diets. Can. J. fish. Aquat. Sci. 40, 281-286.

Higgs, D. A., Fagerlund, U. H. M., Eales, J. G., and McBride, J. R. (1982a). Application of thyroid and steroid hormones as anabolic agents in fish culture. Comp. Biochem. Physiol. 73B (1), 143-176.

Higgs, D. A., McBride, J. R., Markert, J. R., Dosanjh, B. S., Plotnikoff, M. D., and Clarke, W. C. (1982b). Evaluation of Tower and Candle rapeseed (Canola) meal and Bronowski rapeseed protein concentrate as protein supplements in practical dry diets for juvenile chinook salmon (Oncorhynchus tshawytscha). Aquaculture 29, 1-31.

Hossain, M. A., and Jauncey, K. (1988). Toxic effects of glucosinolate (allyl isothiocyanate) (synthetic and from mustard oilcake) on growth and food utilization in common carp. Indian J. Fish. 35, 186-196.

Kühn, E. R., Mol, K. A., and Darras, V. M. (1993). Control strategies of thyroid hormone monodeiodination in vertebrates. Zoological Science 10, 873-885.

Lall, S.P. (1988). Minerals. In « Fish Nutrition » (J.E. Halver, Ed.), pp. 219-257. Academic Press, Inc.

Larsen, D.A., Dickey, J.T. Dickhoff, W.W. (1998). Quantification of salmon thyrotropin- $\beta$ (TSH)-subunit messenger RNA by an RNase protection assay: regulation by thyroid hormones. Gen. Comp. Endocrinol. 107, 98-108. 
Leatherland, J. F., Hilton, J. W., and Slinger, S. J. (1987). Effects of thyroid hormone supplementation of canola meal-based diets on growth, and interrenal and thyroid gland physiology of rainbow trout (Salmo gairdneri). Fish Physiol. Biochem. 3, 73-82.

Leatherland, J.F. (1994). Reflections on the thyroidology of fishes: from molecules to humankind. Guelph Ichthyol. Rev. 2, 1-67.

Lesel, M. (1981). Microflore bactérienne du tractus digestif. In Nutrition des Poissons (M. Fontaine, Ed.), pp. 89-100. Actes Coll. CNERDA, Paris, May 1979, CNRS, Paris.

Lo, M. T., and Hill, D. C. (1971). Effect of feeding a high level of rapeseed meal on weight gains and thyroid function of rats. J. Nut. 101, 975-980.

Ludke, H., Schone, F., and Hennig, A. (1985). Der einfluss von jodkupfer- und zink- zulagen zu rationen mit hohem rapsextraktionsschrotanteil auf wachstum und schildrüssenfunktion des mastschweines. 1. Einfluss auf die mastleistung. Arch. Tierernähr., Berlin 35, 835845.

MacLatchy, D. L., and Eales, J. G. (1993). Effect of $T_{3}$ or $T_{4}$ challenge on inner- and outerring deiodination of $\mathrm{T}_{3}$ and $\mathrm{T}_{4}$ in the liver, kidney, and gill of rainbow trout, Oncorhynchus mykiss. J. Exp. Zool. 265, 637-645.

Martinez, I., Dreyer, B., Argersborg, A., Le Roux, A., and Boeuf, G. (1995). Effect of triiodothyronine and rearing temperature on growth and skeletal myosin heavy chain isoform transition during early development in salmonid (Salvelinus alpinus L.). Comp. Biochem. Physiol. 112B, 717-725.

Mawson, R., Heaney, R. K., Zdunczyk, Z., and Kozlowska, H. (1993). Rapeseed mealGlucosinolates and their antinutritional effects. Part 1. Rapeseed production and chemistry of glucosinolates. Nahrung 37, 131-140. 
Mawson, R., Heaney, R. K., Zdunczyk, Z., and Kozlowska, H. (1994a). Rapeseed mealGlucosinolates and their antinutritional effects. Part 3. Animal growth and performance. Nahrung 38, 167-177.

Mawson, R., Heaney, R. K., Zdunczyk, Z., and Kozlowska, H. (1994b). Rapeseed mealGlucosinolates and their antinutritional effects. Part 4. Goitrogenicity and internal organs abnormalities in animals. Nahrung 38, 178-191.

McCormick, S.D., and Saunders, R.L. (1990). Influence of ration level and salinity on circulating thyroid hormones in juvenile atlantic salmon (Salmo salar). Gen. Comp. Endocrinol. 78, 224-230.

McMillan, M., Spinks, E. A., and Fenwick, G. R. (1986). Preliminary observations on the effect of dietary brussels sprouts on thyroid function. Human Toxicolo. 5, 15-19.

Mol, K., Van der Geyten, S., Burel, C., Darras, V.M., Boujard, T., and Kühn, E.R. (1998). Comparative study of iodothyronine outer ring and inner ring deiodinases activities in five teleostean fishes. Fish Physiol. Biochem 18, 253-266.

Moriyama, S., Swanson, P., Larsen, D. A., Miwa, S., Kawauchi, H., and Dickhoff, W. W. (1997). Salmon thyroid-stimulating hormone: isolation, characterisation, and development of a radioimmunoassay. Gen. Comp. Endocrinol. 108, 457-471.

National Research Council (NRC) (1993). Nutrient Requirements of Fish (Committee on Animal Nutrition, Board on Agriculture, National Research Council, Ed.), 114 p. National Academic Press, Washington, D.C.

Pradet-Balade, B., Schmitz, M., Salmon, C., Dufour, S., and Quérat, B. (1997). Downregulation of TSH subunit mRNA levels by thyroid hormones in the european eel. Gen. Comp. Endocrinol. 108, 191-198. 
Pradet-Balade, B., Burel, C., Dufour, S., Boujard, T., Kaushik, S.J., Quérat, B., and Boeuf, G. (1999). Thyroid hormones down-regulate thyrotropin $\beta \beta$ mRNA level in vivo in the turbot (Psetta maxima). Fish Physiol. Biochem. 20, 193-199.

Quérat, B., Hardy, A., and Fontaine, Y.A. (1991). Regulation of the type-II gonadotropin $\alpha \alpha$ and $\beta \beta$ subunit mRNAs by oestradiol and testosterone in the European eel. J. Mol. Endocrinol., 7, 81-86.

Quinsac, A., Ribaillier, D., Elfakir, C., Lafosse, M., and Dreux, M. (1991). A new approach to the study of glucosinolates by isocratic liquid chromatography. Part I. Rapid determination of desulfated derivatives of rapeseed glucosinolates. J. Assoc. Off. Anal. Chem., 74, 932-939.

Sweeting, R. M., and Eales, J. G. (1992). The acute influence of ingested thyroid hormones on hepatic deiodination pathways in the rainbow trout, Oncorhynchus mykiss. Gen. Comp. Endocrinol. 85, 376-384.

Teskeredzic, Z., Higgs, D. A., Dosanjh, B. S., McBride, J. R., Hardy, R. W., Beames, R. M., Jones, J. D., Simell, M., Vaara, T., and Bridges, R. B. (1995). Assessment of undephytinized and dephytinized rapeseed protein concentrate as sources of dietary protein concentrate as sources of dietary protein for juvenile rainbow trout (Oncorhynchus mykiss). Aquaculture 131, 261-277.

Vermorel, M., and Evrard, J. (1987). Valorization of rapeseed meal. 4. Effects of iodine, copper and ferrous salt supplementation in growing rats. Reprod. Nutr. Dévelop. 27, 769779.

Vermorel, M., Davicco, M.-J., and Evrard, J. (1987). Valorization of rapeseed meal. 3. Effects of glucosinolate content on food intake, weight gain, liver weight and plasma thyroid hormone levels in growing rats. Reprod. Nut. Dévelop. 27, 57-66. 
Virtanen, A. I., Kreula, M., and Kiesvaara, M. (1958). The transfer of L-5-vinyl-2thiooxazolidone (oxazolidinethione) to milk. Acta Chem. Scand. 12 (3), 580-581.

Webster, C. D., Tiu, L. G., Tidwell, J. H., and Grizzle, J. M. (1997). Growth and body composition of channel catfish (Ictalurus punctatus) fed diets containing various percentages of canola meal. Aquaculture 150, 103-112.

Yurkowski, M., Bailey, J. K., Evans, R. E., Tabachek, J.-A. L., and Burton Ayles, G. (1978). Acceptability of rapeseed proteins in diets of rainbow trout (Salmo gairdneri). J. Fish. Res. Board Can. 35, 951-962. 
TABLE 1.

Ingredients and chemical composition of the basic diets used during the experiments

\begin{tabular}{lcccccc}
\hline Ingredients (\%) & Control & R1-10 & R1-20 & R1-30 & R2-30 & R2-50 \\
\hline RM1 & - & 10 & 20 & 30 & - & - \\
RM2 & - & - & - & - & 30 & 50 \\
Fish meal & 48 & 43.5 & 38 & 33.5 & 31.5 & 24.5 \\
Corn flaked & 18 & 15 & 11 & 7 & 6 & - \\
Peas extruded & 16.5 & 13 & 12 & 10 & 13,5 & 5 \\
Fish oil & 11.5 & 12.5 & 13 & 13.5 & 13 & 14.5 \\
Common part $^{1}$ & 6 & 6 & 6 & 6 & 6 & 6 \\
\hline Dry matter (\%) $_{\text {Crude protein (\% DM) }}$ & 84.8 & 87.0 & 85.1 & 86.7 & 86.2 & 89.3 \\
Crude fat (\% DM) $_{\text {Gross Energy (kJ/g DM) }}$ & 12.0 & 15.6 & 44.7 & 43.7 & 40.6 & 47.5 \\
Phosphorus (\% DM) $^{\text {Iodine (mg/kg DM) }}{ }^{2}$ & 1.6 & 1.5 & 15.2 & 17.6 & 17.9 & 15.3 \\
& $1.2-2.7$ & $1.2-2.6$ & $1.1-2.3$ & $1.1-2.2$ & $1.0-2.1$ & $1.0-1.8$ \\
\hline Total GLS measured $^{3}$ & & 2.2 & 5.0 & 7.3 & 4.1 & 1.4 \\
Theoretical GLS $^{3}$ & & 2.4 & 4.8 & 7.2 & 11.2 & 18.7 \\
Equivalent breakdown products $^{3}$ & 1.5 & 2.4 & 3.7 & 7.1 & 17.4 \\
\hline
\end{tabular}

${ }^{1}$ Common part: 3\% soluble fish protein concentrate (CPSP-G, Sopropêche, France); 1\% vitamin mixture (NRC, 1993); 1\% mineral mixture (in g or $\mathrm{mg} / \mathrm{kg}$ diet : calcium carbonate (40\% Ca), 1.12 g; magnesium oxide (60\% Mg), $0.62 \mathrm{~g}$; ferric citrate, $0.1 \mathrm{~g}$; potassium iodide (75\% I), $0.2 \mathrm{mg}$; zinc sulphate ( $36 \% \mathrm{Zn}), 0.2 \mathrm{~g}$; copper sulphate $(25 \% \mathrm{Cu}), 0.15 \mathrm{~g}$; manganese sulphate (33\% Mn), 0.15 g; dibasic calcium phosphate (20\% Ca, 18\% P), 2.5 g; cobalt sulphate, 1 mg; sodium selenite ( $30 \%$ Se), $1.5 \mathrm{mg}$; KCl, 0.45g; NaCl, $0.2 \mathrm{~g}$ ); $1 \%$ binder (alginate).

2 The total dietary iodine levels were estimated from the ingredients iodine contents given by Ferrando and Blum (1989).

${ }^{3}$ See text 
TABLE 2.

Growth performance of trout (initial body weight: 22g) fed the experimental diets during 58 days in Experiment 1.

\begin{tabular}{lccccc}
\hline & Control & R1-10 & R1-20 & R1-30 & R2-50 \\
\hline Final body weight (g) & $60.9 \pm 1.7^{\mathrm{b}}$ & $64.6 \pm 5.8^{\mathrm{b}}$ & $61.3 \pm 1.1^{\mathrm{b}}$ & $62.0 \pm 1.9^{\mathrm{b}}$ & $44.3 \pm 0.5^{\mathrm{a}}$ \\
DGI (\% /day) $^{\mathrm{a}}$ & $2.2 \pm 0.1^{\mathrm{b}}$ & $2.3 \pm 0.4^{\mathrm{b}}$ & $2.1 \pm 0.1^{\mathrm{b}}$ & $2.2 \pm 0.1^{\mathrm{b}}$ & $1.4 \pm 0.1^{\mathrm{a}}$ \\
${\text { VFI (\%ABW } \times \text { day) }^{2}}^{2}$ & $2.4 \pm 0.4^{3}$ & $2.3 \pm 0.6$ & $2.3 \pm 0.3$ & $2.3 \pm 0.2$ & $3.0 \pm 0.3$ \\
Feed Efficiency $^{3}$ & $0.98 \pm 0.14^{\mathrm{b}}$ & $1.00 \pm 0.21^{\mathrm{b}}$ & $0.97 \pm 0.04^{\mathrm{b}}$ & $0.95 \pm 0.04^{\mathrm{b}}$ & $0.61 \pm 0.02^{\mathrm{a}}$ \\
\hline
\end{tabular}

Note. Means are indicated with standard deviation $(\mathrm{n}=3)$. Superscript letters indicate intergroup statistical differences (one way ANOVA and Tukey's multiple range analysis; $P<0.05$ ) between dietary conditions. IBW, FBW and ABW are initial, final and average body weights, respectively.

${ }^{1}$ Daily growth index $=100 \times\left((\mathrm{FBW})^{1 / 3}-(\mathrm{IBW})^{1 / 3}\right) /$ duration

${ }^{2}$ Average of voluntary feed intake calculated for each period as follow: VFI $=100 \times$ dry feed intake (g) / ( (IBW + FBW) / 2) $\times$ duration

${ }^{3}$ Average of feed efficiency calculated for each period: FE = wet weight gain (g) / dry feed intake (g) 
TABLE 3.

Coefficients of retention (\% of intake) for nitrogen, phosphorus and energy in trout (initial body weight: 24 g) fed the experimental diets during 55 days in Experiment 2.

\begin{tabular}{lccccc}
\hline Dietary treatments & Control & R2-50 & R2-50-I & R2-50-T $_{3} 10$ & R2-50-T $_{3} 20$ \\
\hline Nitrogen & $39.0 \pm 2.9^{\mathrm{d}}$ & $15.2 \pm 0.6^{\mathrm{a}}$ & $24.1 \pm 1.3^{\mathrm{b}}$ & $18.2 \pm 1.6^{\mathrm{a}}$ & $17.8 \pm 1.7^{\mathrm{a}}$ \\
Phosphorus & $29.6 \pm 2.6^{\mathrm{d}}$ & $10.9 \pm 1.1^{\mathrm{a}}$ & $19.8 \pm 0.6^{\mathrm{c}}$ & $15.2 \pm 0.6^{\mathrm{b}}$ & $15.3 \pm 1.2^{\mathrm{b}}$ \\
Energy & $44.9^{\mathrm{a}} \pm 5^{\mathrm{c}}$ & $21.1 \pm 1.8^{\mathrm{a}}$ & $32.4^{\mathrm{a}} \pm 2.0^{\mathrm{b}}$ & $18.6 \pm 3.0^{\mathrm{a}}$ & $22.9 \pm 1.8^{\mathrm{a}}$ \\
\hline
\end{tabular}

Note. Means ( \pm standard deviation, $\mathrm{n}=3$ ), for each dietary treatment, with no common letter are significantly different (one way ANOVA and Tukey’s multiple range test; $P<0.05$ ). 


\section{TABLE 4.}

Effect of THS treatment (200 mg/l) on the In vitro D1 activity (conversion of $\mathrm{rT}_{3}$ ) measured in kidney, D2 activity (conversion of $\mathrm{T}_{4}$ ) in liver, and D3 activity (conversion of $\mathrm{T}_{3}$ ) in liver and brain measured $24 \mathrm{~h}$ after injection in trout (mean weight around $55 \mathrm{~g}$ ) fed with a control diet or with a RM2-based diet for 64 days (Experiment 2).

\begin{tabular}{|c|c|c|c|c|}
\hline & \multicolumn{2}{|c|}{ Control diet } & \multicolumn{2}{|c|}{ R2-50 diet } \\
\hline & Sham & TSH & Sham & TSH \\
\hline $\begin{array}{l}\text { D1 kidney } \\
{\text { fmol } \mathrm{rT}_{3} / \mathrm{mg} \text { protein/min }}\end{array}$ & $227 \pm 75$ & $165 \pm 68$ & $193 \pm 19$ & $168 \pm 18$ \\
\hline $\begin{array}{l}\text { D2 liver } \\
\text { fmol } \mathrm{T}_{4} / \mathrm{mg} \text { protein/min }\end{array}$ & $12 \pm 5^{a}$ & $21 \pm 13^{a}$ & $212 \pm 4^{b}$ & $201 \pm 15^{b}$ \\
\hline $\begin{array}{l}\text { D3 liver } \\
\mathrm{fmol}_{3} / \mathrm{mg} \text { protein } / \mathrm{min}\end{array}$ & $3.68 \pm 1.81^{b}$ & $4.93 \pm 2.75^{b}$ & $0.25 \pm 0.44^{\mathrm{a}}$ & $0.37 \pm 0.78^{a}$ \\
\hline $\begin{array}{l}\text { D3 brain } \\
\text { fmol } \mathrm{T}_{3} / \mathrm{mg} \text { protein/min }\end{array}$ & $4.71 \pm 1.28^{b}$ & $5.72 \pm 1.53^{b}$ & $1.66 \pm 0.33^{a}$ & $2.22 \pm 0.49^{a}$ \\
\hline
\end{tabular}

Note. Means ( \pm standard deviation ; tissues pooled by $5, \mathrm{n}=3$ ) for each treatment with no common letter are significantly different $(P<0.05$, one-Way ANOVA and Tuckey's multiple range test). 


\section{FIGURE LEGENDS}

FIG 1. Changes over time in plasma concentrations of thyroxine ( $\left.T_{4}\right)$ (A) and triiodothyronine $\left(\mathrm{T}_{3}\right)(\mathrm{B})$ in Experiment 1 . Means ( \pm standard deviation, $n=15$ ) sharing no common superscript letter are significantly different $(P<0.05$, one-way ANOVA and Tukey’s multiple range test).

FIG 2. Changes over time of in vitro deiodinase activities for each dietary treatment in Experiment 1: D1 activity in kidney (A, deiodination of $\mathrm{rT}_{3}$ ), $\mathrm{D} 2$ activity in liver (B, deiodination of $\mathrm{T}_{4}$ ) and $\mathrm{D} 3$ activity in liver and brain (C and 3D, deiodination of $\mathrm{T}_{3}$ ). Means ( \pm standard deviation; $n=3$, samples pooled by 5 ) with no common superscript letter are significantly different $(P<0.05$, one-way ANOVA and Tukey’s multiple range test).

FIG 3. Plasma concentrations of $\mathrm{T}_{3}$ and $\mathrm{T}_{4}(\mathrm{~A})$, daily growth index (B), voluntary feed intake and feed efficiency (C) measured in trout (FBW of 54 g) after 2 months of dietary treatment in Experiment 2. The RM2 based diet was supplemented with 10 or $20 \mathrm{mg} / \mathrm{kg}$ of $\mathrm{T}_{3}$ or with 1 $\mathrm{mg} / \mathrm{kg}$ of iodine. Means ( \pm standard deviation, $\mathrm{n}=15$ ) with no common letter are significantly different ( $P<0.05$, one-way ANOVA and Tukey’s multiple range test).

FIG 4. In vitro D1 activity (conversion of $\mathrm{rT}_{3}$ ) measured in kidney (A), D2 activity (conversion of $\mathrm{T}_{4}$ ) in liver (B), and D3 activity (conversion of $\mathrm{T}_{3}$ ) in liver and brain (C) in trout (mean weight around 50g) after 2 months of dietary treatment in Experiment 2. The RM2 based diet was supplemented with 10 or $20 \mathrm{mg} / \mathrm{kg}$ of $\mathrm{T}_{3}$ or with $1 \mathrm{mg} / \mathrm{kg}$ of iodine. Means ( \pm standard deviation; tissues pooled by $5, n=3$ ) with no common letter are significantly different $(P<0.05$, one-way ANOVA and Tukey’s multiple range test).

FIG 5. Effect of TSH treatments (sham saline solution, $100 \mathrm{mg} / \mathrm{l}$ of TSH or $200 \mathrm{mg} / \mathrm{l}$ of TSH) on plasma concentrations of $\mathrm{T}_{3}$ and $\mathrm{T}_{4}$, measured $24 \mathrm{~h}$ after injection, in trout (mean weight around 55g) fed with a control diet or with a RM2-based diet for 64 days in Experiment 2. 
Means ( \pm standard deviation ; $=9$ ) with no common letter are significantly different $(P<0.05$, one-way ANOVA and Tukey’s multiple range test).

FIG 6. Plasma concentrations of $T_{3}$ and $T_{4}(A)$, specific growth rate (B), and voluntary feed intake (VFI) and feed efficiency (FE) (C) measured in trout after two months (fish mean weight around $90 \mathrm{~g}$ ), then after 6 months (fish mean weight around $300 \mathrm{~g}$ ) of feeding in Experiment 3. The RM1-based diet was supplemented with $2 \mathrm{mg} / \mathrm{kg}$ of iodine. Means ( \pm standard deviation; $\mathrm{n}=15)$ with no common letter are significantly different $(P<0.05$, oneway ANOVA and Tukey’s multiple range test).

FIG 7. Changes over time of trout mean weight in relation with the experimental diet intake in Experiment 3. For each sample time, * indicates a statistical difference between dietary treatments with $P<0.05$ (one-way ANOVA). Means ( \pm standard deviation; $n=3$ ) with no common letter are significantly different (Tukey’s multiple range test).

FIG 8. Effect of aquatic environment on plasma concentrations of $T_{3}$ and $T_{4}$ measured in trout (initial mean weight around $160 \mathrm{~g}$ ) fed with a control diet or with two RM-based diets for 25 days in Experiment 4. Means ( \pm standard deviation; $n=15$ ) with no common letter are significantly different ( $P<0.05$, two-ways ANOVA and Tukey’s multiple range test).

FIG 9. Main processes of action of the glucosinolates in rainbow trout. Two asterisks, original observations; one asterisk, observations made during this study that are not original; question mark, processes not yet clearly demonstrated in fish. 

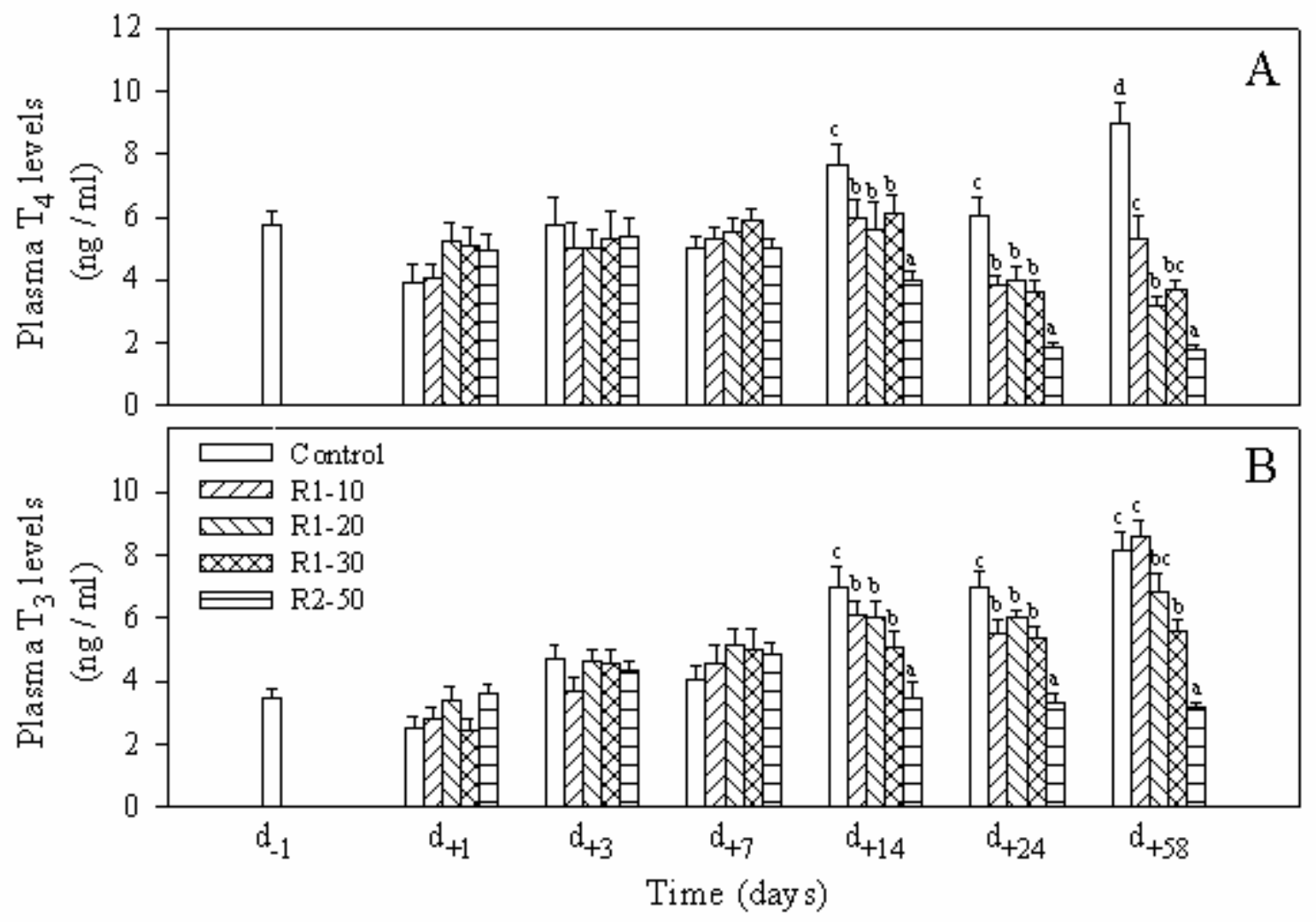

Figure 1.

Burel et al. "Effects and way of action of the rapeseed meal-glucosinolates on the thyroid metabolism, growth and feed utilisation in rainbow trout" 

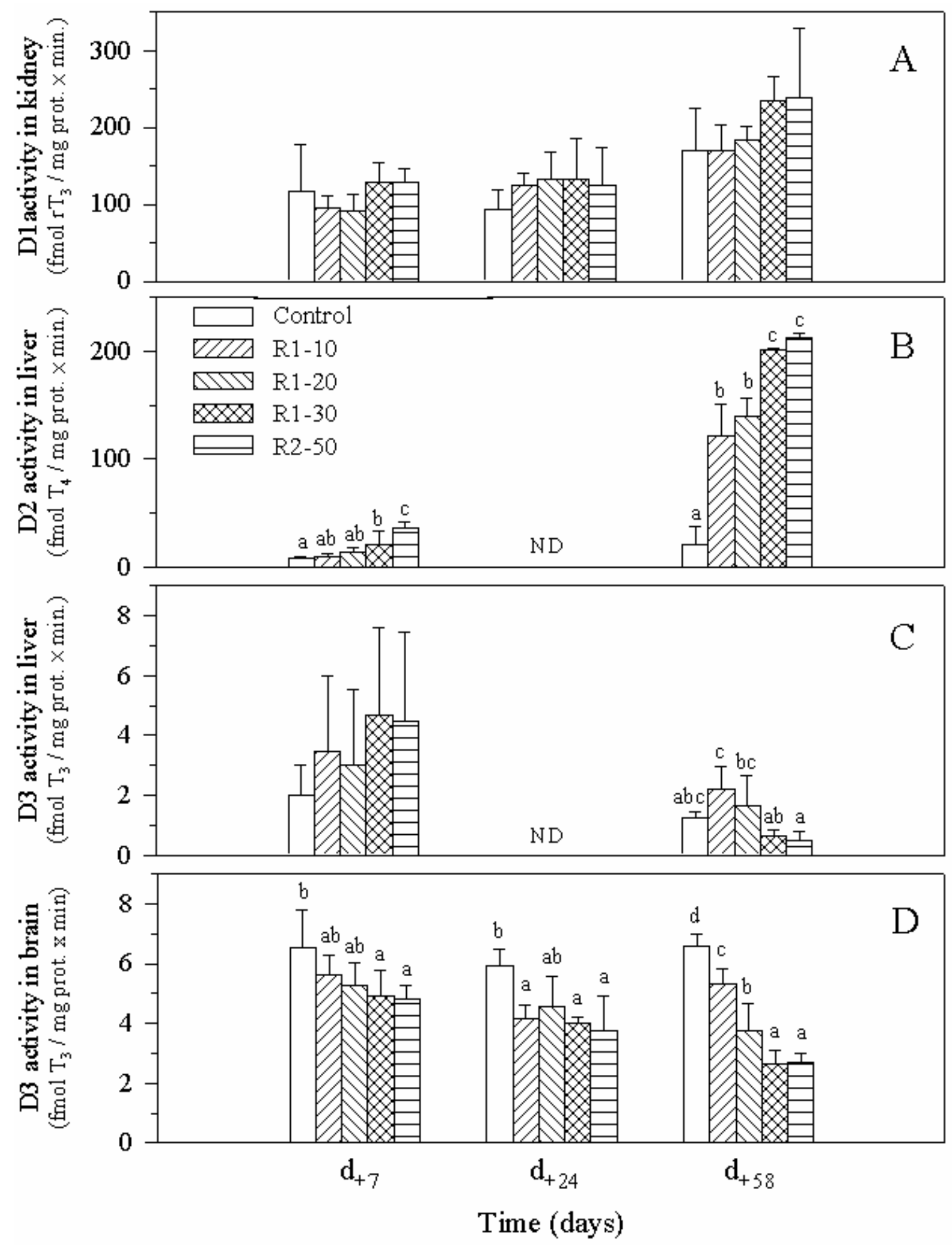

Figure 2

Burel et al. "Effects and way of action of the rapeseed meal-glucosinolates on the thyroid metabolism, growth and feed utilisation in rainbow trout" 

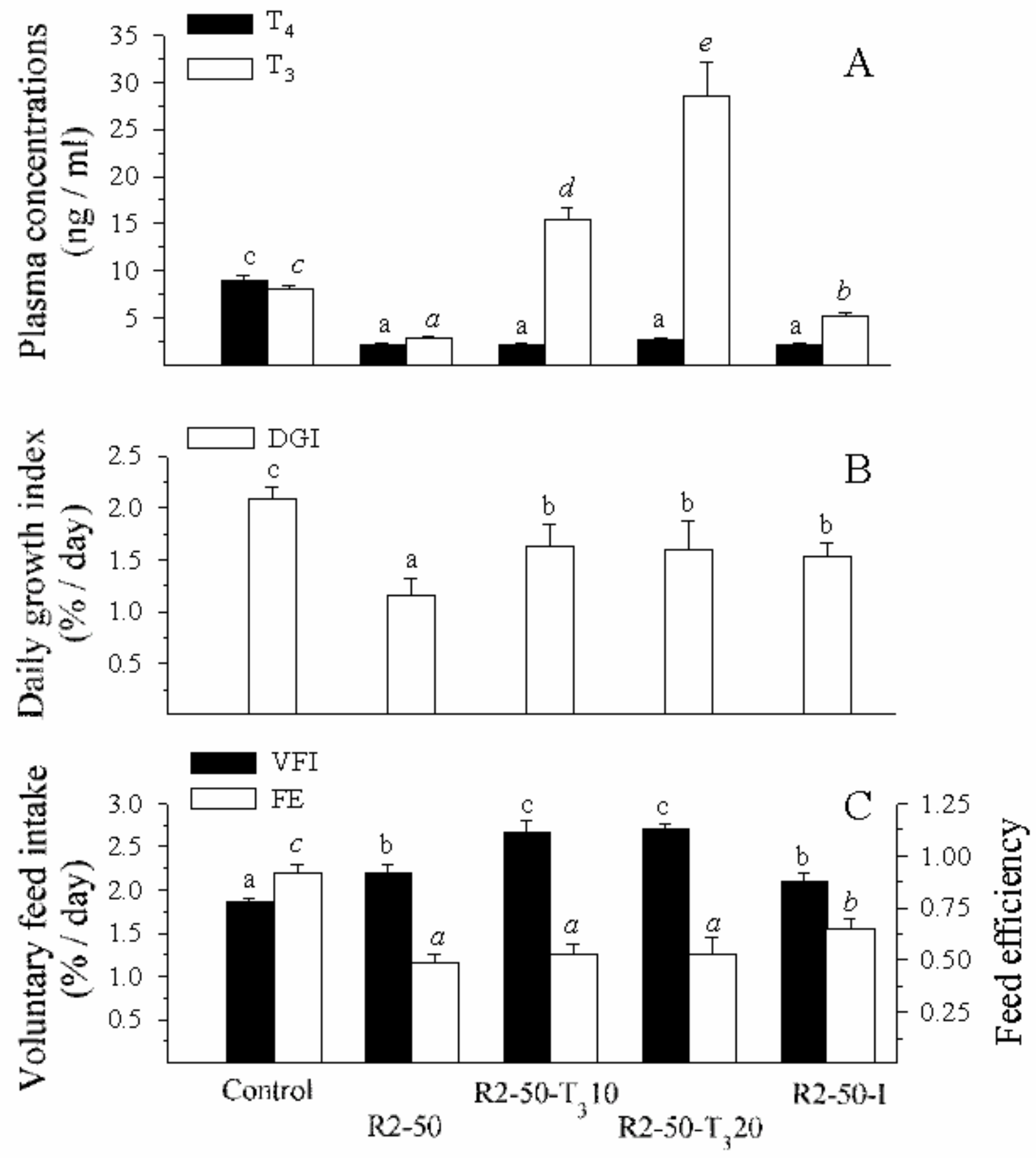

Figure 3

Burel et al. "Effects and way of action of the rapeseed meal-glucosinolates on the thyroid metabolism, growth and feed utilisation in rainbow trout" 

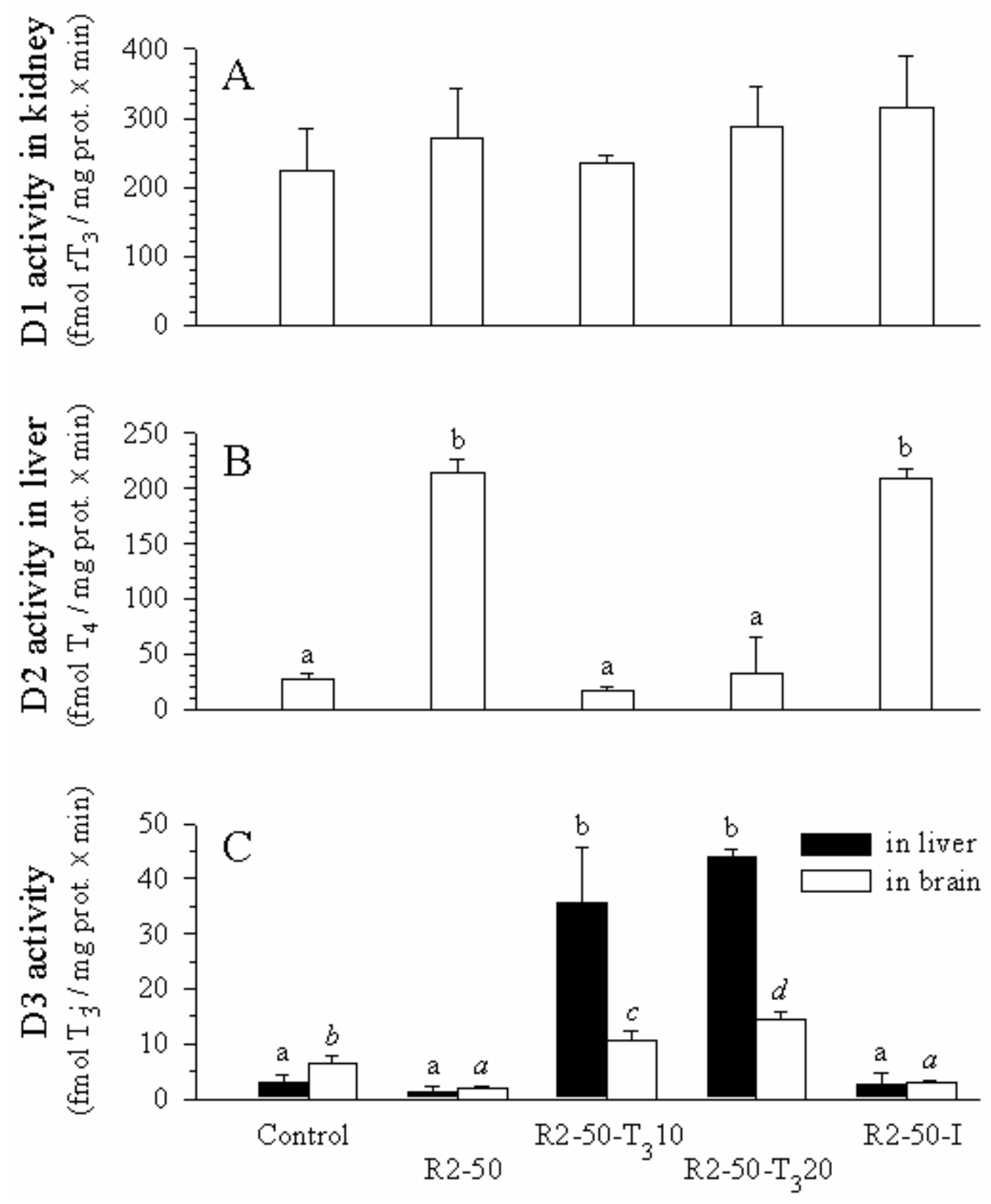

Figure 4

Burel et al. "Effects and way of action of the rapeseed meal-glucosinolates on the thyroid metabolism, growth and feed utilisation in rainbow trout" 


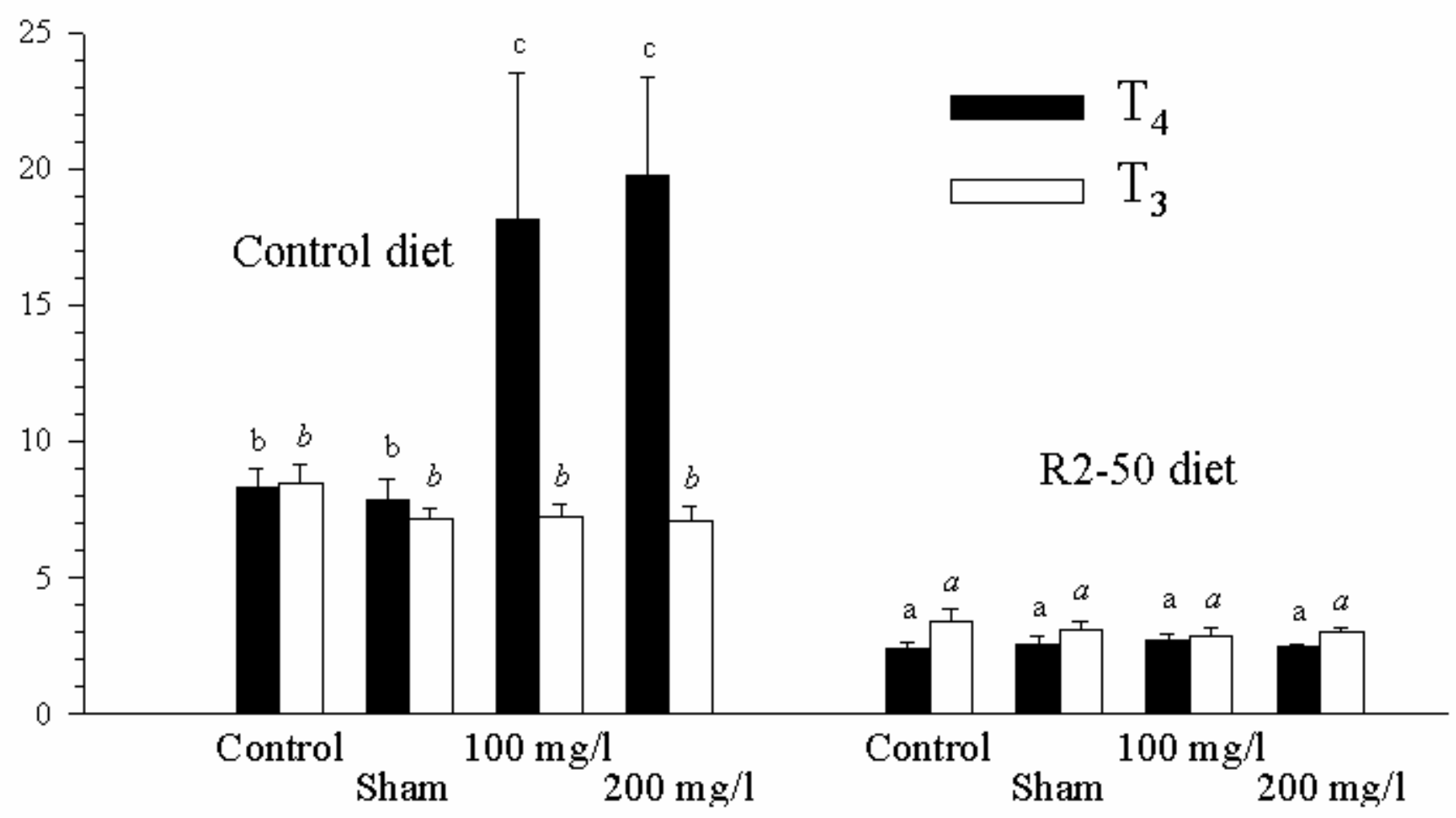

Figure 5

Burel et al. "Effects and way of action of the rapeseed meal-glucosinolates on the thyroid metabolism, growth and feed utilisation in rainbow trout" 

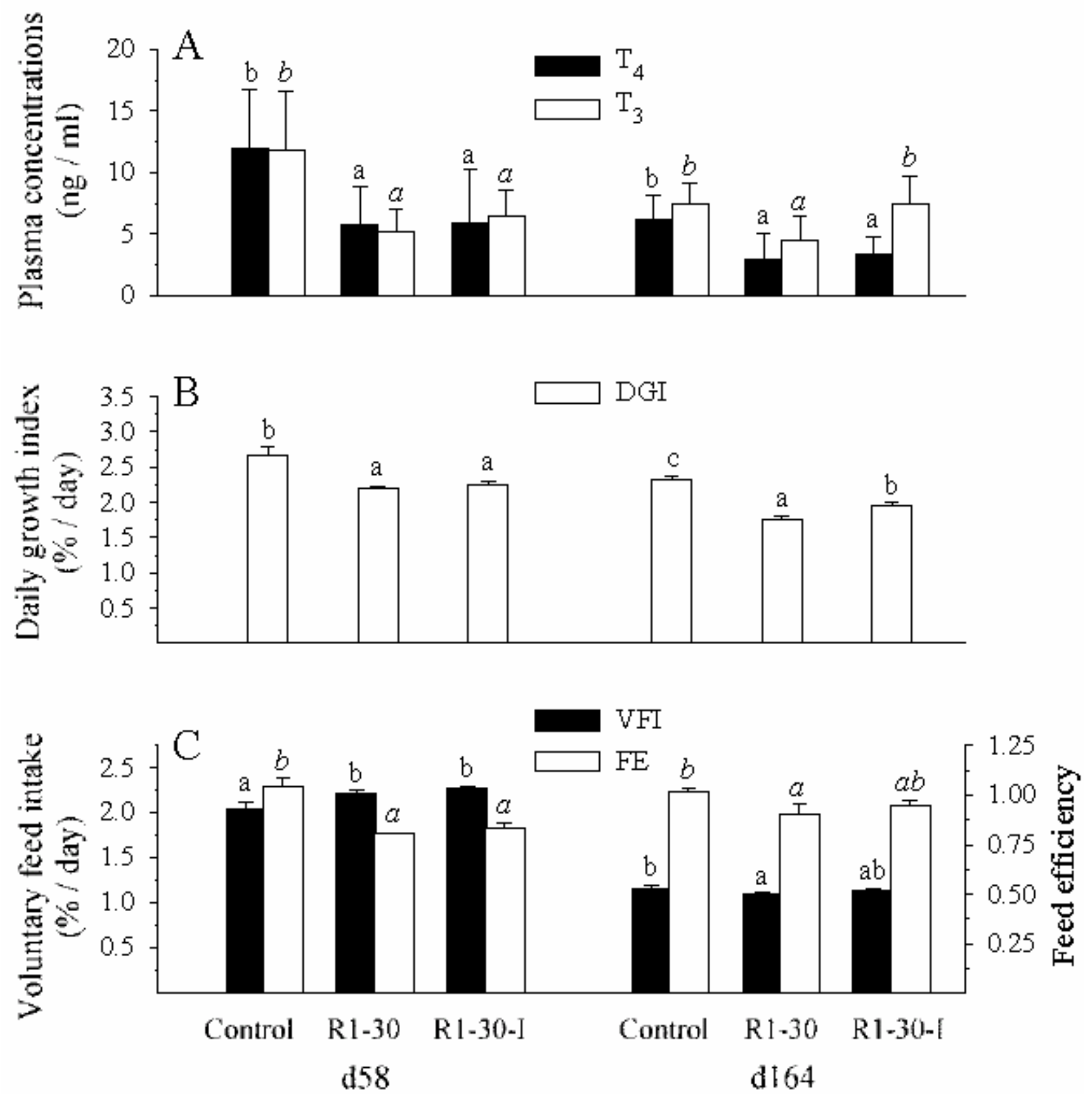

Figure 6

Burel et al. "Effects and way of action of the rapeseed meal-glucosinolates on the thyroid metabolism, growth and feed utilisation in rainbow trout" 


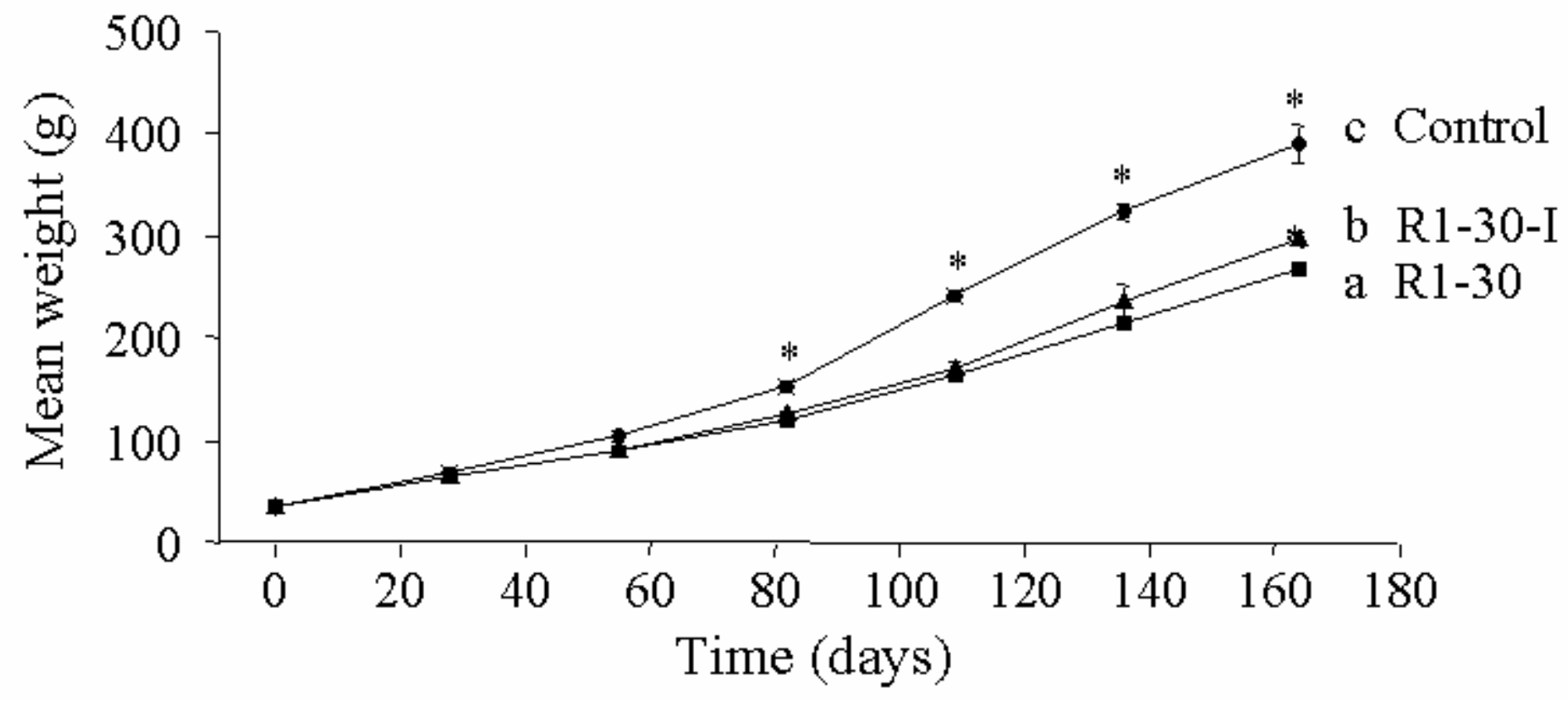

Figure 7

Burel et al. "Effects and way of action of the rapeseed meal-glucosinolates on the thyroid metabolism, growth and feed utilisation in rainbow trout" 


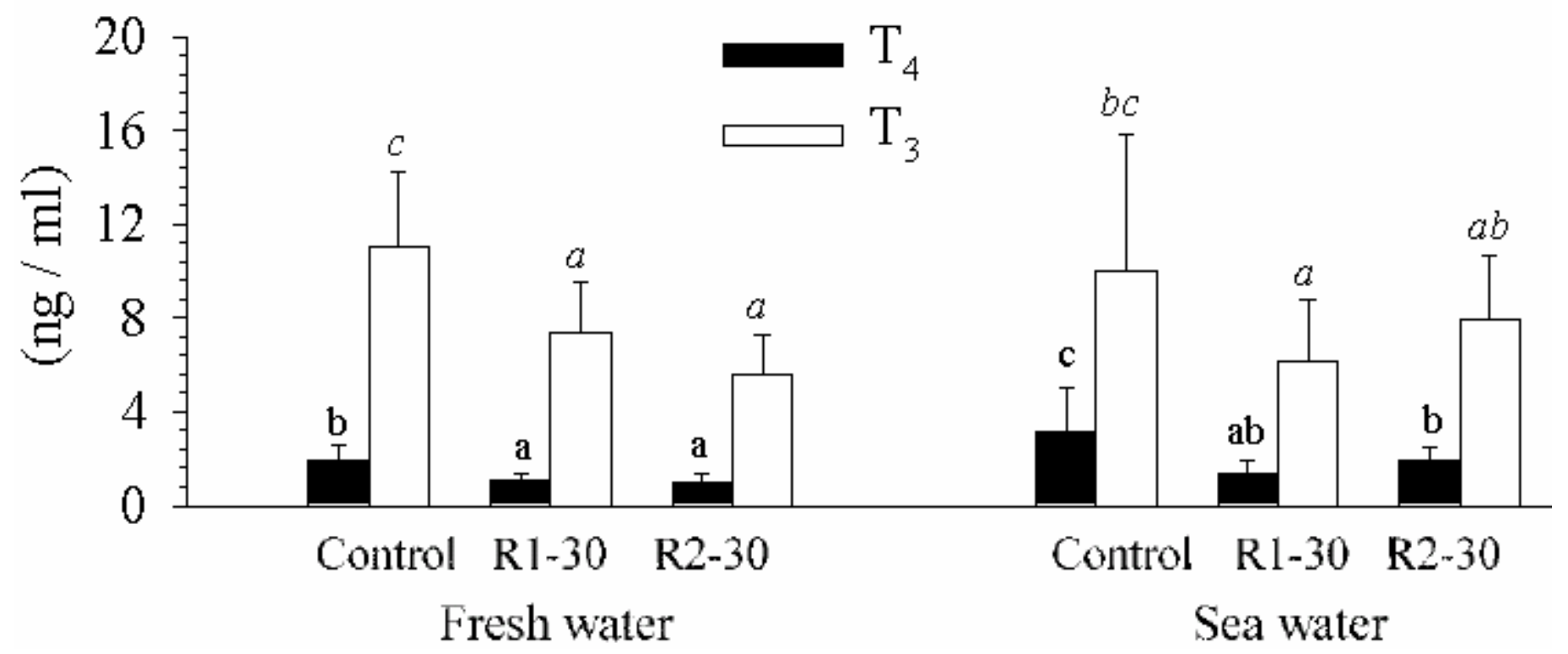

Figure 8

Burel et al. "Effects and way of action of the rapeseed meal-glucosinolates on the thyroid metabolism, growth and feed utilisation in rainbow trout" 


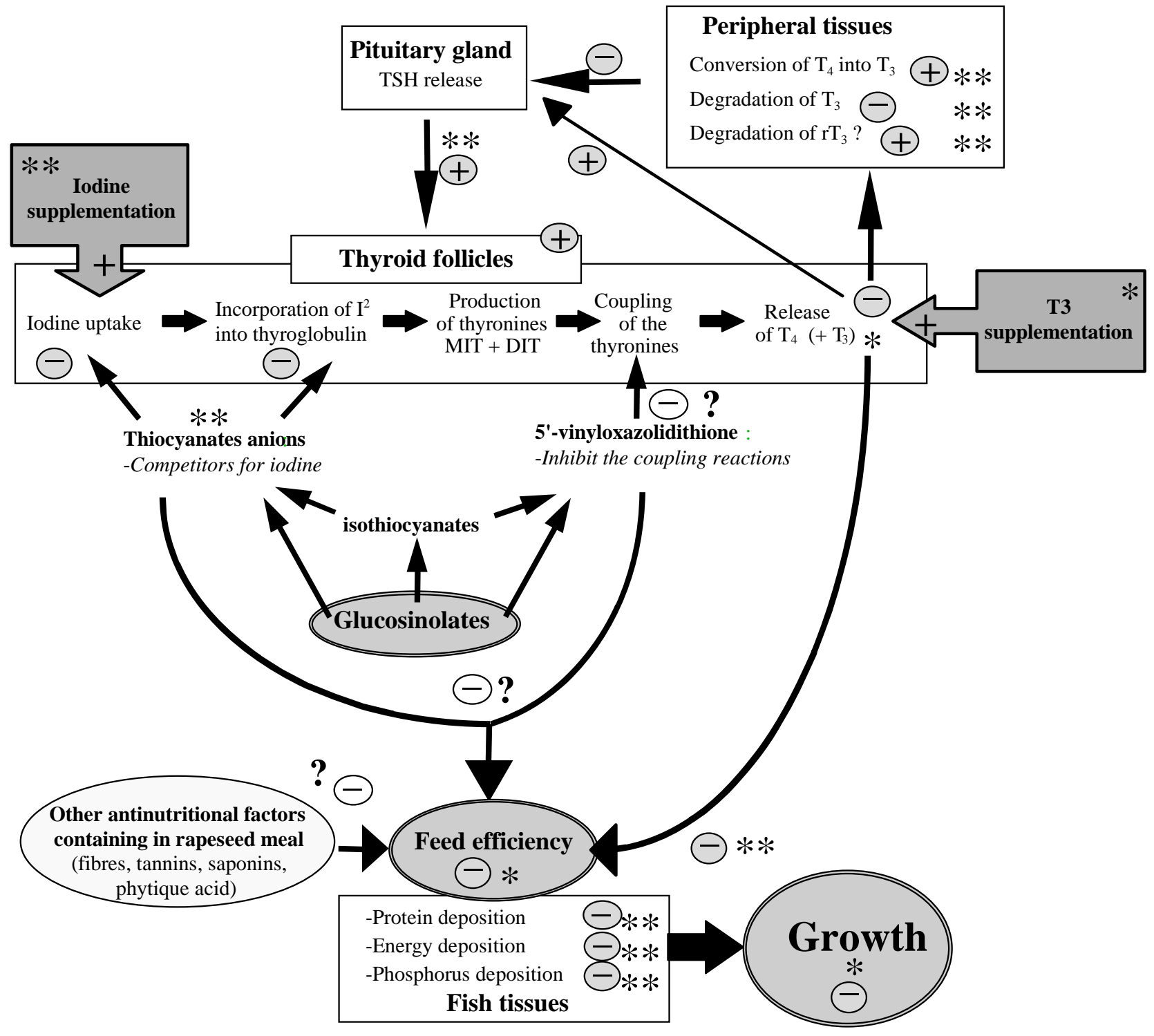

Figure 9

Burel et al. "Effects and way of action of the rapeseed meal-glucosinolates on the thyroid metabolism, growth and feed utilisation in rainbow trout ” 